New Zealand journal of industrial relations, 1989, 14, 241-250

\title{
How does New Zealand compare now? International comparisons of disaggregated unemployment data
}

\author{
Peter Brosnan and Moira Wilson*
}

This article updates Hicks and Brosnan's 1982 study which compared disaggregated unemployment data for Australia, Norway, the UK and the USA with similar data from New Zealand. It is found that women, youth and non-white workers bear a disproportionate share of the unemployment burden and the unemployment burden is distributed more inequitably in New Zealand than in any of the other 4 countries.

\section{Introduction}

Seven years ago, Hicks and Brosnan (1982) conducted an analysis of disaggregated unemployment data. They compared New Zealand unemployment statistics with those for 4 countries which had some other similarities to New Zealand. They demonstrated that while New Zealand had comparatively low rates of unemployment, the distribution of unemployment in New Zealand was considerably less equitable than in the other 4 countries.

The intervening period has seen changes in the international economy and profound changes in New Zealand. Registered unemployment in New Zealand averaged just over 48,000 in 1981. The corresponding average for 1988 was 121,000 . Whereas most countries experienced economic growth after the mid 1980s, New Zealand suffered serious economic decline. This decline and the subsequent growth in unemployment was the direct result of the Labour Government's policies in both the public and private sectors. Thousands of staff were shed from government departments where inefficiency was equated with the number on the payroll, while other departments were turned into State Owned Enterprises and their managers also attempted to achieve efficiencies by reducing the number employed. Similar effects occurred in sectors such as health, where reduced levels of government funding resulted in substantial staff cuts.

Reduced employment in the public sector led to demand contraction in the private sector. Moreover, other government policies exacerbated the effect on this. The abrupt removal of border protection and the promotion of CER substantially reduced employment. Manufacturing employment fell by more than 15 percent between December 1985 and December 1988. There were significant second-round reductions in possible by grants from the Faculty of Commerce and Administration and the Internal Research Grant Committee. Their support and the referee's comments are gratefully acknowledged. 
other sectors such as building and construction, where employment fell by 11 percent. The interaction of these outcomes with the Government's restrictive monetary and fiscal policies further reduced employment overall. Despite substantial growth in the financial sector, total employment fell by 5 percent. The number of unemployed continued to grow and stood at 144,000 in April 1989. The effect of these policies was far from uniform. The South Island and rural areas suffered much more than the North Island and the metropolitan areas.

Given the changes in the economy and the growth of unemployment over the last 7 years, there is no a priori reason to suppose that Hicks and Brosnan's (1982) findings should still hold. Accordingly, in this note, we update Hicks and Brosnan's research on New Zealand and make appropriate comparisons with the same 4 countries used in thei original analysis, namely Australia, Norway, the USA and the UK. ${ }^{1}$ The analysis in this paper is aided by the availability of the better unemployment statistics provided by the Household Labour Force Survey. These are only available from late 1985 and therefore, for comparative purposes, registration data will be used in most of the tables. 2

At the outset it is useful to summarise Hicks and Brosnan's (1982) findings:

(i) Throughout the 1970s, New Zealand had lower rates of unemployment than all the major OECD countries, and, in particular, had lower rates of unemployment than Australia, Norway, the USA and the UK, the countries selected for comparison.

(ii) In most countries, including New Zealand, women had higher rates of unemployment than men, but New Zealand women accounted for a greate proportion of total unemployment, when their share of the labour force was taken into consideration, than women in any of the other countries in the comparison.

(iii) Although youth unemployment rates were lowest in New Zealand, young workers of both sexes accounted for a higher proportion of the unemployed in New Zealand than in any of the other 4 countries.

(iv) Long term unemployment was also borne disproportionately by the young to a greater extent in New Zealand than in any of the other countries, particularly so in the case of young women.

(v) Disadvantage for ethnic minorities in unemployment was at least as great in New Zealand as it was in the USA, and was most severe for young Polynesian (Maori and Pacific Island) women.

We turn now to the comparisons of recent data.

\section{Unemployment level}

If we look first at unemployment at the aggregate level, New Zealand's unemployment history differs from that of the other 4 countries in degree and in profile. Table 1 provides a comparison of unemployment experience. In the 1960s and early 1970s the unemployment rate in New Zealand was minimal and relatively constant while the other countries, more exposed to creeping economic recession, experienced significant unemployment. As New Zealand's unemployment began to soar in the mid 1980s, the unemployment rates of other countries were beginning to drop. Australia had had lower than average unemployment rates in the 1960 s and early 1970 s and then experienced above average rates which fell for the first time between 1987 and 1988. Unemployment rates in the USA were consistently above average until they began to drop in the mid 1980s. The UK suffered the highest incidence of unemployment of the 5 countries; its unemployment rate peaked at 11.2 percent in 1987. Norway's unemployment, like New Zealand's, continues an upward trend in the late 1980s, although it remains at

1 The criteria for selection are discussed in detail in Hicks and Brosnan (1982)

2 A comparison of the two data sources and their relative utility is provided by Brosnan (1986) comparatively minimal levels. In 1988, the unemployment rate in New Zealand was the highest of the 5 countries and was moving in the opposite direction to the overall trend for advanced countries. This constitutes a radical reversal of New Zealand's position in international comparison in the $1970 \mathrm{~s}$

Table 1: Standardised unemployment rates in selected countries (a)

\begin{tabular}{|c|c|c|c|c|c|c|}
\hline Country & $\begin{array}{l}\text { Average } \\
\text { 1964-1973(b) }\end{array}$ & $\begin{array}{l}\text { Average } \\
\text { 1974-1979(b) }\end{array}$ & $\begin{array}{l}\text { Average } \\
1980-1985\end{array}$ & 1986 & 1987 & 1988 \\
\hline USA & 4.4 & 6.6 & 8.0 & 6.9 & 6.1 & 5.4 \\
\hline Japan & 1.2 & 1.9 & 2.4 & 2.8 & 2.8 & 2.5 \\
\hline Germany & 0.8 & 3.2 & 6.0 & 6.4 & 6.2 & 6.2 \\
\hline France & 2.2 & 4.5 & 8.3 & 10.4 & 10.6 & 10.3 \\
\hline UK & 3.1 & 5.1 & 10.5 & 11.2 & 10.3 & 8.3 \\
\hline Italy & 5.5 & 6.6 & 8.8 & 10.9 & 11.8 & n.a. \\
\hline Canada & 4.7 & 7.2 & 9.9 & 9.5 & 8.8 & 7.8 \\
\hline Australia & 1.9 & 5.0 & 7.6 & 8.0 & 8.1 & 7.2 \\
\hline Finland & 2.3 & 4.5 & 5.1 & 5.3 & 5.0 & 4.5 \\
\hline Norway & 1.7 & 1.8 & 2.6 & 2.0 & 2.1 & 3.2 \\
\hline Spain & 2.8 & 5.6 & 16.6 & 21.0 & 20.1 & 19.1 \\
\hline Sweden & 2.0 & 1.9 & 2.9 & 2.7 & 1.9 & 1.6 \\
\hline TOTAL (c) & 3.0 & 4.9 & 7.5 & 7.7 & 7.4 & $7.0^{(\mathrm{d})}$ \\
\hline New Zealand & 0.3 & 0.9 & $4.2(\mathrm{e})$ & $5.6(f)$ & $7.1^{(f)}$ & $9.9(f)$ \\
\hline
\end{tabular}

(b) From Hicks and Brosnan (1982)

(c) Total for the OECD.

(d) Total for the OECD countries above.

(e) From ILO figures.

(f) The unemployment figures used to calculate the unemployment rates for 19861988 were the calendar year averages of monthly recordings of registered unemployment. The measures of labour force size used were the calendar year averages of quarterly figures.

Source: ILO Yearbook of labour statistics; OECD Quarterly Labour Force Statistics; NZ Dept. of Labour Monthly Employment Operations; NZ Dept. of Statistics The New Zealand labour force.

Given that the unemployment rate is the sum of widely varying unemployment experiences of different population sub-groups, it is likely that changes in the aggregate unemployment rates have been associated with changes in the distribution of unemployment. Below, we compare changes in disaggregated unemployment.

\section{Unemployment by sex}

Table 2 compares unemployment rates by sex. There is no general pattern of change in the sex structure of unemployment. Hicks and Brosnan found that for each of the countries, with the exception of the United Kingdom, the female unemployment rate exceeded the male rate and was rising the most rapidly in the 1970s. This is no longer true. In general men have borne a greater proportion of unemployment in the 1980s. The exception is still the United Kingdom. The table shows that in the United Kingdom, the unemployment rate of women has been consistently lower than that for men. In the first half of the $1980 \mathrm{~s}$, however, the male unemployment rates grew faster in New 
Zealand, Australia and Norway, and declined more slowly in the USA, so that the proportionate difference between the unemployment rates of men and women gradually closed. By 1988, unemployment was dropping in Australia and the USA but continued to grow in New Zealand and Norway. Many of the those who lost jobs in the New Zealand public sector were male, and males were further affected by the decline of manufacturing and job losses in building and construction. The growth of male unemployment in New Zealand was so severe that the male rate surpassed the rising female unemployment rate by 1986, and the gap between the rates continued to widen with accelerated unemployment growth in the period 1986-1988. The gap closed in the United Kingdom too, but the change was less marked.

Whereas Hicks and Brosnan found that New Zealand women's share of unemployment was rising in the 1970s, their share fell as unemployment increased in the 1980s. Despite this, by 1988 , New Zealand women had the highest propensity to be unemployed of women in any of the 5 countries.

\begin{tabular}{|c|c|c|c|c|}
\hline Australia & Norway & UK & US & New Zealand \\
\hline
\end{tabular}

\begin{tabular}{|c|c|c|c|c|c|c|c|c|c|c|}
\hline $1974^{(a)}$ & 1.9 & 4.1 & 1.0 & 2.3 & 3.7 & 1.1 & 4.8 & 6.7 & 0.1 & 0.1 \\
\hline $1980^{(\mathrm{a}}$ & 5.1 & 7.9 & 1.2 & 2.3 & 8.7 & 5.7 & 6.9 & 7.4 & 2.6 & 3.3 \\
\hline 1986 & 7.7 & 8.4 & 1.5 & 2.5 & 14.1 & 10.3 & 6.8 & 7.1 & 5.8 & 5.1 \\
\hline 1988 & 6.7 & 7.8 & 3.0 & 3.4 & 10.0 & 6.2 & 5.3 & 5.5 & 10.7 & 8.5 \\
\hline
\end{tabular}

Notes: (a) From

Source: ILO Yearbook of labour statistics; OECD Quarterly labour force statistics; NZ Dept. of Labour Monthly employment operations; NZ Dept. of Statistics The New Zealand labour force.

\section{Youth unemployment}

Hicks and Brosnan demonstrated that all countries experienced high and rising youth unemployment in the 1970s. Further, although youth unemployment rates were highe in Australia, the UK and the USA, in New Zealand, more so than in these other countries, unemployment was primarily a problem of young workers, particularly young women. Table 3(a) updates Hicks and Brosnan's findings. Youth unemployment increased by less than the total in all 5 countries during the 1980s as older workers were affected more severely by unemployment growth and affected less by unemployment reductions. The male and female youth unemployment rates in New Zealand dropped from nearly 3.5 and 3.8 times the overall rate to 2.2 and 2.8 times the overall rate respectively; in the 4 other countries these dropped from around 3 times to around 2 to 2.5 times the total unemployment rate.
Table 3(a):Youth ${ }^{(a)}$ and total unemployment by sex

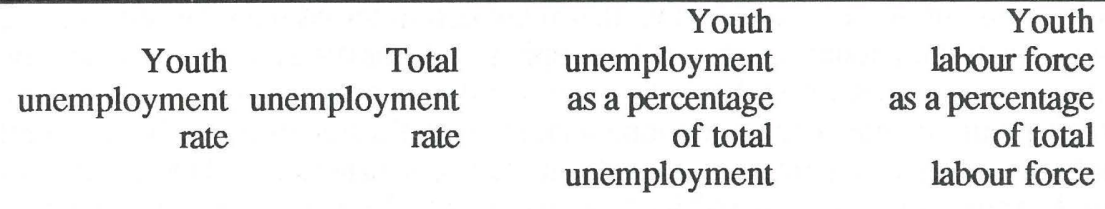

\section{$\overline{\text { Male Female }} \overline{\text { Male Female }} \overline{\text { Male Female }} \quad \overline{\text { Male Female }}$}

\begin{tabular}{|c|c|c|c|c|c|c|c|c|}
\hline \multicolumn{9}{|c|}{ Australia } \\
\hline $1980^{\text {(b) }}$ & 14.5 & 18.6 & 5.0 & 7.4 & 29.1 & 38.2 & 9.9 & 15.2 \\
\hline 1986 & 18.7 & 19.5 & 7.7 & 8.4 & 21.6 & 29.5 & 8.9 & 12.7 \\
\hline \multicolumn{9}{|l|}{ Norway } \\
\hline $1980^{(b)}$ & 4.2 & 3.0 & 1.3 & 1.2 & 17.5 & 21.0 & 5.3 & 6.6 \\
\hline 1986 & 3.5 & 3.2 & 1.5 & 2.5 & 10.9 & 12.7 & 5.3 & 6.7 \\
\hline \multicolumn{9}{|l|}{$\mathbf{U K}$} \\
\hline $1980^{(b)}$ & 17.6 & 16.2 & 7.2 & 5.2 & 19.0 & 34.7 & 7.8 & 11.2 \\
\hline 1986 & 23.8 & 20.7 & 14.1 & 10.3 & 12.8 & 20.2 & 7.6 & 10.0 \\
\hline \multicolumn{9}{|l|}{ USA } \\
\hline $1979^{(\mathrm{b})}$ & 15.0 & 16.3 & 4.9 & 6.8 & 26.3 & 24.9 & 8.6 & 10.4 \\
\hline 1986 & 19.0 & 17.7 & 6.8 & 7.1 & 17.3 & 18.2 & 6.1 & 7.3 \\
\hline \multicolumn{9}{|c|}{ New Zealand } \\
\hline $1980^{(b)}$ & 7.0 & 10.0 & 2.0 & 2.6 & 35.3 & 64.1 & 10.0 & 16.6 \\
\hline 1986 & 12.9 & 14.2 & 5.8 & 5.1 & 17.5 & 33.6 & 7.9 & 12.2 \\
\hline $1988^{(c)}$ & 22.8 & 21.4 & 10.6 & 8.5 & 15.4 & 28.1 & 7.2 & 11.2 \\
\hline
\end{tabular}

Notes: (a) Youth aged under 20

(b) From Hicks and Brosnan (1982)

(c) The youth labour force defined as those under 20

Source: ILO Yearbook of labour statistics; OECD Quarterly labour force statistics; Aust. Bureau of Statistics The labour force; US Dept. of Labour Employment and earnings; NZ Department of Labour Monthly employment operations; NZ Dept. of Statistics The New Zealand labour force.

\section{Table 3(b):Youth (a) and total unemployment by sex 1988}

$\begin{array}{rrrr}\begin{array}{r}\text { Youth } \\ \text { unemployment } \\ \text { rate }\end{array} & \begin{array}{r}\text { Total } \\ \text { unemployment } \\ \text { rate }\end{array} & \begin{array}{r}\text { Youth } \\ \text { as a percentage } \\ \text { of total }\end{array} & \begin{array}{r}\text { Youth } \\ \text { as a percentage } \\ \text { of total } \\ \text { unemployment }\end{array} \\ & & \text { labour force }\end{array}$

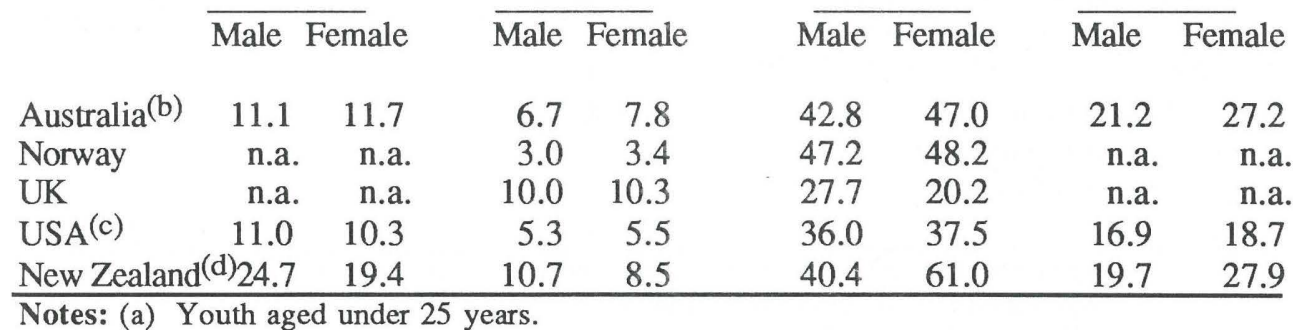

b) The size of the youth labour force based on figures for October 1988.

(c) The size of the youth labour force based on figures for November 1988.

(d) Youth unemployment at October 1988.

Source: Same as table 3(a) 
Table 3(a) shows that, to some extent, there is a relationship between the proportion of unemployed that are youth workers and the proportion of the labour force they constitute. Australian and New Zealand youth, who accounted for relatively high proportions of unemployment in 1986, also accounted for relatively high proportions of the labour force in their respective countries. Participation in the labour force by those under 20 years was very low in Norway, and accordingly their share of unemployment was low. When youth are defined as workers aged under 25 (presented in Table $3(\mathrm{~b})$ ), the Even considering the relative size of the youth labour force, however, New Zealand youth workers had a more disproportionately large share of unemployment than youth in other countries in 1980. Although by 1986 the share of unemployment held by young male workers in New Zealand had become less disproportionate than in the USA and Australia, the share of unemployment held by young New Zealand female workers remained the most disproportionately large. By 1988, New Zealand still had among the largest proportion of unemployment borne by young male workers and by far the largest share of female unemployment borne by women under 25 . Three fifths of unemployed females but only one quarter of the female full-time labour force was under 25 .

\section{Age, sex and long-term unemployment}

Hicks and Brosnan also examined the distribution of long-term unemployment across different demographic groups. Tables 4 update their findings. Despite the change in definition of long-term unemployment from 3 months to 6 months between 1978 and the most recent figures, in all cases except the USA, the proportion of unemployment that is long-term has remained relatively constant; increase in the level of unemployment, where it occurred, was associated with increase in the duration of unemployment. New Zealand remains about average for the 5 countries. Unemployment for more than 3 months duration increased from one third to one half of total unemployment between 1978 and 1988 , and at the latter date more than one quarter of the unemployed had been jobless for more than 6 months. In contrast, at both dates and under both definitions of long-term unemployment, Australia and the UK had very high incidence of long-term unemployment, and Norway and the USA had proportionately little long-term unemployment.

Table 4(a): Share of long-term unemployment over three months: 1978 (percentages)

\begin{tabular}{|c|c|c|c|c|}
\hline Group & Australia & Norway & UK & USA \\
\hline Youths (a) & 54.9 & 5.7 & 31.7 & 36.4 \\
\hline Prime age workers (b) & 30.6 & 44.1 & 34.5 & 38.3 \\
\hline Older workers ${ }^{(c)}$ & 14.5 & 50.1 & 33.9 & 25.3 \\
\hline Males & 57.2 & 45.6 & 26.5 & 41.9 \\
\hline Females & 42.7 & 54.4 & 73.5 & 58.1 \\
\hline Unemployment rate & 6.3 & 1.8 & 5.5 & 5.9 \\
\hline $\begin{array}{l}\text { Long-term unemploym } \\
\text { as a percentage of total }\end{array}$ & ent & 194 & 618 & 228 \\
\hline
\end{tabular}

b) Aged 25-45 years (20-49 in Norway).

(c) Aged over 45 years (50 in Norway).

Source: OECD Economic outlook; OECD Quarterly labour force statistics; Central Bureau of Statistics of Norway Arbeidsmarked statistikk (Labour market statistics); Aust. Bureau of Statistics The labour force: US Dept. of Labour Employment and earnings: HMSO Central Statistical Office Social trends; NZ Dept. of Labour Monthly employment operations.
Table 4(b): Share of long-term unemployment over 6 months: latest figures (percentages)

\begin{tabular}{|c|c|c|c|c|}
\hline Group & $\begin{array}{c}\text { Australia }^{(a)} \\
1986 \\
\end{array}$ & $\begin{array}{c}\text { Norway } \\
1987\end{array}$ & $\begin{array}{c}\text { UK } \\
1988 \\
\end{array}$ & $\begin{array}{c}\mathrm{USA}^{(\mathrm{b})} \\
1988 \\
\end{array}$ \\
\hline Youths $(\mathrm{c})$ & 35.3 & 16.7 & 26.4 & 15.7 \\
\hline Prime age workers $(\mathrm{d})$ & 55.6 & 50.0 & 49.5 & 71.4 \\
\hline Older workers (e) & 9.1 & 33.3 & 24.1 & 12.9 \\
\hline Males & 61.7 & n.a. & 72.7 & 68.6 \\
\hline Females & 38.3 & n.a. & 27.3 & 31.4 \\
\hline Unemployment rate & 7.2 & 2.0 & 10.3 & 5.4 \\
\hline $\begin{array}{l}\text { Long-term unemployn } \\
\text { as a percentage of tota } \\
\text { unemployment }\end{array}$ & 48.2 & 15.0 & 61.3 & 10.3 \\
\hline
\end{tabular}

Notes:- (a) As at October quarter.
(b) As at November.
(c) Aged less than 25 years
(d) Aged 25-49 in Norway and the UK, and $25-54$ in USA and Australia.
(d) Aged $25-49$ in Norway and the UK, and 25 - 54 in USA and Australia. Source: Same as table 4(a).

Table 4(c): Share of long-term unemployment: New Zealand (percentages)

\begin{tabular}{|c|c|c|c|}
\hline Group & $\begin{array}{r}1981 \\
\text { unemployment } \\
\text { over 3 months }\end{array}$ & $\begin{array}{r}1988^{(\mathrm{a})} \\
\text { unemployment } \\
\text { over 3 months }\end{array}$ & $\begin{array}{r}1988^{(\mathrm{a})} \\
\text { unemployment } \\
\text { over } 6 \text { months }\end{array}$ \\
\hline Youths (b) & 54.9 & 41.0 & 37.5 \\
\hline Prime age workers (c) & 28.8 & 37.5 & 38.0 \\
\hline Older workers $(\mathrm{d})$ & 16.3 & 21.4 & 24.4 \\
\hline Males & 41.5 & 74.5 & 73.7 \\
\hline Females & 58.5 & 25.5 & 26.3 \\
\hline Unemployment rate & 1.8 & 9.9 & 9.9 \\
\hline $\begin{array}{l}\text { Long-term unemploy } \\
\text { as a percentage of tota } \\
\text { unemployment }\end{array}$ & $\begin{array}{l}\text { yment } \\
\text { tal }\end{array}$ & 52.4 & 27.6 \\
\hline
\end{tabular}

Notes (a) Registered unemployed as at October - excludes vacation workers.

(b) Aged less than 25 years.

(c) Aged 25-39.

(d) Aged 40 or more

Source: Same as table 4(a).

The apparent correspondence between the rate of unemployment and the proportionate extent of long-term unemployment is explained by the fact that if the overall level of unemployment is low, the relative importance of short-term frictional unemployment is greater.

Hicks and Brosnan found that in New Zealand and Australia, most of those unemployed for more than three months were under 25 , whereas in the other countries, prime aged workers held the largest share of long term unemployment. They found that in all countries, except New Zealand and Australia, most of the long-term unemployed were women. The latest figures indicate that New Zealand and Australia are no longer exceptions; on the one hand, men have come to dominate long-term unemployment in 
Norway, the UK and the USA as well as in New Zealand and Australia; on the other hand, the relative preponderance of youth among the long term unemployed has declined in New Zealand and Australia so that prime aged workers now bear the largest share of long-term unemployment in all countries.

Table 4(c) shows that the the largest increases in long-term unemployment in New Zealand, under both the three month and the six month definitions, have been among prime aged workers; the proportion of long-term unemployment accounted for by young workers declined and the burden shifted to prime aged and, to a lesser extent, older workers (cf. Brosnan and Hicks, 19

New Zealand anc

New Zealand and the UK had the greatest sex imbalance among the long-term unemployed of all the countries under study. Although the increase in male long-term unemployment was most severe in the UK, there was a substantial increase in the proportion of males among long-term unemployed in New Zealand too, in line with the overall shift in the representation of the sexes among the total unemployed.

\section{Racial disadvantage}

Examination of the incidence of unemployment of different racial and ethnic groups is limited to a comparison of the United States and New Zealand by the paucity of data for other countries. Hicks and Brosnan found that, in 1981, black workers in the USA were two and a half times more likely than white workers to be unemployed, and that young blacks were particularly disadvantaged. Members of the Polynesian racial minorities in New Zealand, however, were more severely disadvantaged with rates of unemployment nearly 4 times the non-Polynesian rates. Young Polynesian women had the highest unemployment rate, and their share of total unemployment was 9 times their share of the labour force.

As unemployment has fallen in the United States, the disadvantage of black and Hispanic workers has remained fairly constant. Table 5 shows that black workers remain around two and a half times more likely to be unemployed than white. The disadvantage of Hispanic workers is slightly less - they are around 1.8 times more likely to be unemployed. In contrast, the disadvantage of Polynesian workers has intensified under unemployment growth in New Zealand. Between 1986 and 1988, the unemployment rate of Pacific Island Polynesians in New Zealand increased at a much faster rate than total unemployment, mainly due to the decline in manufacturing over that period (Brosnan and Wilson, 1989). They are over three times more likely to be unemployed than Pakeha workers. Male Maori workers experienced substantial unemployment growth, but at about the same pace as Pakeha workers. The differential between their unemployment rate and that for male Pakeha workers fell from 3.7 in 1986 to 3.5 in 1988. Although unemployment growth for Maori females was less extreme, the differential between their unemployment rate and that for Pakeha females increased. It would appear that the disadvantage associated with being non-white remains greater in New Zealand than in the United States, and is worsening for some groups.

\section{Conclusion}

We can now summarise the findings of this paper:

(i) New Zealand now has higher unemployment than most OECD countries and in particular has higher rates than Australia, Norway, the USA and the UK.

(ii) In most countries, women have higher rates of unemployment than men but in the
Table 5: Surveyed unemployment rates by ethnic origin in New Zealand and the USA Ethnic Origin

1986

Male $\quad$ Female

\begin{tabular}{llrrrr} 
& Male & Female & Male & Female \\
\hline USA & & & & \\
& White & 5.5 & 6.2 & 4.3 & 4.4 \\
& Black & 14.9 & 14.9 & 10.8 & 10.5 \\
& Hispanic & 10.2 & 11.2 & 7.6 & 7.3 \\
TOTAL & 6.5 & 7.3 & 5.0 & 5.2 \\
New Zealand & & & & \\
$\quad$ Pakeha (European) & 2.6 & 3.9 & 4.9 & 4.5 \\
& Maori & 9.8 & 11.0 & 17.3 & 17.3 \\
& Pacific Island Polynesian & 6.9 & 6.0 & 15.0 & 14.4 \\
& TOTAL & 3.3 & 4.5 & 6.1 & 6.0 \\
&
\end{tabular}

Source: US Dept. of Zealand Labour Force.

UK, and now in New Zealand, men have higher rates. New Zealand women had the highest propensity to be unemployed out of the 5 countries.

(iii) Youth are still the most likely to be unemployed but the share of unemployment borne by older workers has been increasing in each country. Young New Zealand women bore a larger share of their country's unemployment than their counterparts in the other 4 countries.

(vi) Long term unemployment is increasingly a problem for prime age workers. In every other country youths and older workers are less likely to be unemployed long term. In New Zealand also youth are less likely to be unemployed long term, but the share of long term unemployment borne by older age workers has also increased.

(v) The disadvantaged position of non-whites remains worse in New Zealand than in the United States.

In general, New Zealand has been following the international trend, albeit with a lag, in terms of both the scale of unemployment and the impact on different groups. What is most striking though is the suddeness and scale of the deterioration in employment following the implementation of the Rogernomics programme.

The country whose experience appears most similar to New Zealand's is the UK. Unemployment peaked there in 1986 and has declined since. However, the UK paid a high price for its sustained period of severe recession. Significant sections of manufacturing were largely destroyed and recent attempts at reflating the economy have produced near double digit inflation while leaving millions still unemployed. The effects on the British economy may have been worse had the exploitation of North Sea Oil not provided a more favourable exchange rate. New Zealand has not found such a resource as North Sea Oil and the Rogernomics programme was introduced quicker and more ruthlessly than Thatcherism. If there is anything to be learnt from the British and recent New Zealand experience, it would seem likely that New Zealand's unemployment will get worse, last for many years, and increasingly affect males, prime age workers of both sexes, and Maori and Pacific Island workers.

\section{References}

Australian Bureau of Statistics (various issues) The labour force Canberra. 
Brosnan, P (1986) Surveyed and registered unemployed: a comparison New Zealand population review 12(3): 246-251.

Brosnan, P and Hicks, J (1986) The concentration of unemployment experience in spells of long duration: an analysis by age and sex New Zealand journal of industrial relations 11(2): 161-175.

Brosnan, P and Wilson, M (1989) Labour market segmentation, migrant workers and restructuring. In Economic restructuring and migrant labour in the South Pacific Wellington, Social Sciences Research Fund Committee.

Central Bureau of Statistics of Norway Arbeidsmarked statistikk (Labour market statistics) Oslo.

Hicks, J and Brosnan, P (1982) How does New Zealand compare? Some international comparisons of disaggregated unemployment data New Zealand journal of industrial relations $7(2):$ 107-122.

ILO (various issues) Yearbook of labour statistics Geneva.

New Zealand Department of Labour (various issues) Monthly emploment operations Wellington.

New Zealand Department of Statistics (various issues) The New Zealand labour force Wellington.

O.E.C.D. (various issues) Economic outlook.

O.E.C.D. (various issues) Quarterly labour force statistics.

United States Department of Labour Employment and earnings Washington.

United Kingdom Central Statistical Office Social trends London. 